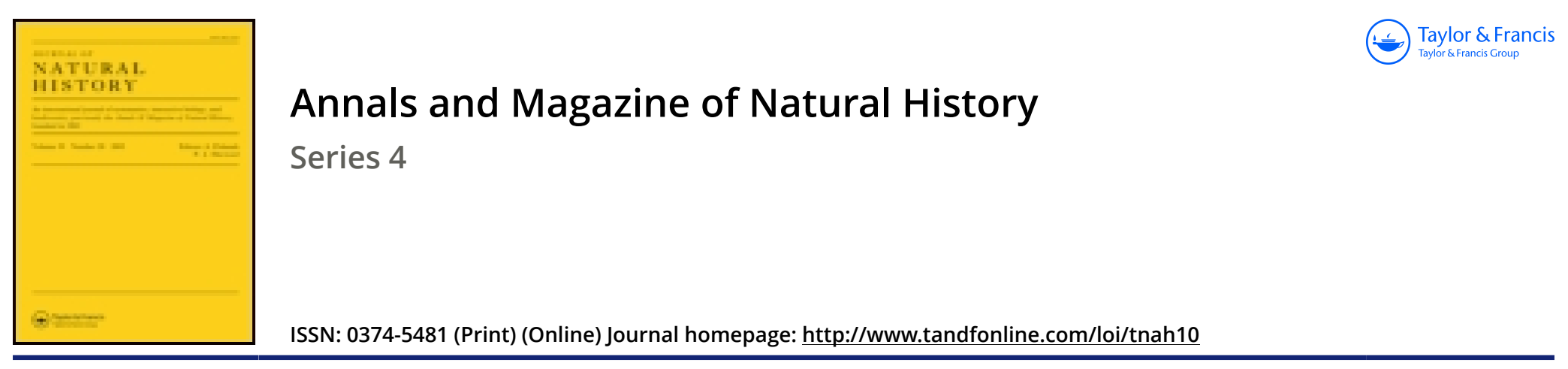

\title{
The habitat of Labaria hemisphærica
}

\section{Dr. J.E. Gray F.R.S.}

To cite this article: Dr. J.E. Gray F.R.S. (1874) The habitat of Labaria hemisphærica, Annals and Magazine of Natural History, 13:74, 188-188, DOI: 10.1080/00222937408680840

To link to this article: http://dx.doi.org/10.1080/00222937408680840

$$
\text { 曲 Published online: } 13 \text { Oct } 2009 .
$$

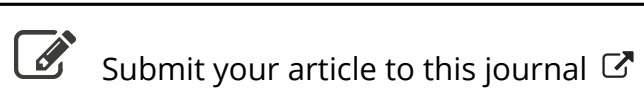

Џll Article views: 1

Q View related articles ¿ 
Telamonides belonged to the same brood; the former consists of earlier, the latter of later individuals from wintering chrysalids; the second brood of the species (the first from short-lived chrysalids) is Marcellus, and made up of the mingled progeny of both Walshii and Telamonides.-From an advance proof of the Proceedings of the Boston Society of Natural History, October 22, 1873.

The Habitat of Labaria hemisphærica.

By Dr. J. E. GruY, F.R.S. \&e.

In reply to Dr. Meyer's communication at p. 66 , I see I am wrong in not giving Cebu as the habitat of these sponges; but as I received the box of sponges some time after $I$ received the letter containing their habitat, although he said I should receive the two together, I had forgotten that the one referred to the other. I am astonished to observe that Dr. Meyer says, "I obtained these sponges from the reefs in the sea near the village Talisay," because the specimen of Labaria we received had, when dried, separated into two parts-a hemispherical sponge and a long tuft of broken spicules of Euplectella, tied at one end by a strip of a spotted silk handkerchief, which had been affixed into the base of the hemisphere! Dr. Meyer, in a letter of November 6th, 1873 , says, "I wondered to hear that the largest one proved to be artificially made up; if $I$ am not mistaken, I got still some specimens of the same kind, but they did not yet arrive in Europe." In a note just received (Jan. 21st) Dr. Meyer says:- - I looked through those bottles and dried several sponges. My Malay boy from Ternate was charged with this business, and perhaps he may have tied something together or done another mischief with them; or this may have been made by those fishermen at Talisay, I having overlooked it before I started, as I said, in a hurry."

On the Steppe-Cat of Bokhara (Chaus caudatus).

By Dr. J. E. Gray, F.R.S. \&c.

The Zoological Department of the British Museum has lately received the skin and skull of a Chaus from the steppes of Bokhara. It is very like the common jungle-cat (Felis chaus) from more southern Asia in the thickness and softness of the fur, in the general colouring, and in the tufts of the ears; but it differs from it in having a considerably longer tail, reaching nearly to the groundhence its name Chaus caudatus in the description of it which has been read at the Zoological Society, illustrated by a beautiful figure by Mr. Wolf. 